\title{
Toxicological profile of deltamethrin in Triatoma brasiliensis (Hemiptera: Reduviidae) in State of Ceará, Northeastern Brazil
}

\author{
Grasielle Caldas D'Ávila Pessoa ${ }^{[1]}$, Nathália Abreu Borges Trevizani ${ }^{[1]}$, Letícia Sena Dias ${ }^{[1]}$, \\ Claudia Mendonça de Bezerra ${ }^{[2]}$, Bernardino Vaz de Melo ${ }^{[3]}$ and Liléia Diotaiuti ${ }^{[1]}$
}

[1]. Laboratório de Triatomíneos e Epidemiologia da Doença de Chagas, Centro de Pesquisas René Rachou, Fundação Oswaldo Cruz, Belo Horizonte, MG. [2]. Secretaria de Saúde do Estado do Ceará, Fortaleza, CE. [3]. Secretaria de Saúde do Estado de Minas Gerais, Belo Horizonte, MG.

\begin{abstract}
Introduction: Triatoma brasiliensis is the species of greatest epidemiological relevance in the semi-arid region of Brazil. This species is predominantly found in domestic environments, and it has the ability to build large colonies with high levels of natural infection via Trypanosoma cruzi. Thus, T. brasiliensis is one of the most efficient transmitters of Chagas disease (CD) to humans. Despite household spraying with residual insecticides, many areas report persistent reinfestations for reasons that remain poorly understood. Therefore, this study sought to characterize the toxicological profile of deltamethrin in T. brasiliensis from areas with persistent reinfestation in State of Ceará, Brazil. Methods: The susceptibility reference lineage (SRL) was derived from Umari. Serial dilutions of deltamethrin were prepared and applied to the dorsal abdomen of first instar nymphs. The control group received only pure acetone. Mortality was evaluated after $72 \mathrm{~h}$. Qualitative tests assessed mortality in response to a diagnostic dose of $1 \mathrm{xLD}_{99}(0.851$ nanograms of active ingredient per treated nymph) of the SRL. Results: The susceptibility profile characterization of the T. brasiliensis populations revealed $50 \%$ resistance ratios $\left(\mathrm{RR}_{50}\right)$ that ranged from 0.32 to 1.21 . The percentage of mortality in response to the diagnostic dose was $100 \%$. Conclusions: We demonstrated that T. brasiliensis was highly susceptible to deltamethrin. The control difficulties found might be related to the recolonization of the triatomines originating from neighboring environments and the possible operational failures related to the process of spraying that enabled specimens less susceptible to deltamethrin to survive.
\end{abstract}

Keywords: Triatominae. Triatoma brasiliensis. Insecticide resistance. Deltamethrin.

\section{INTRODUCTION}

Chagas disease ${ }^{(1)}(\mathrm{CD})$ affects approximately 1.8 to 2.5 million people in Brazil. This disease is endemic to much of the country and targets entire populations with poor access to basic public health services (sanitation, housing, health, and so on). After many years of effort and investment in housing improvements and chemical control, home triatomine levels have been significantly reduced in general, especially those of Triatoma infestans. However, studies of existing autochthonous species show that the effective entomological surveillance led by endemic/health agents, in partnership with the general population, must be conducted to maintain this result.

\footnotetext{
Address to: Dra. Liléia Diotaiuti. Lab. de Triatomíneos e Epidemiologia da Doença de Chagas/CPqRR/FIOCRUZ. Av. Augusto de Lima 1715, Barro Preto, 30190-002 Belo Horizonte, MG, Brasil.

Phone: 5531 3349-7762; Fax: 5531 3295-3115

e-mail: diotaiuti@cpqrr.fiocruz.br

Received 12 January 2015

Accepted 23 February 2015
}

In many regions of Brazil, humans are in close contact with triatomines because of the proximity and overlap of domestic and wild environments, which often occurs in the Brazilian semi-arid region. The species of greatest epidemiological relevance in this region is Triatoma brasiliensis. Studies conducted in Bahia ${ }^{(2)}$, Piaui $^{(3)}$ and Ceará ${ }^{(4)}$ have indicated that T. brasiliensis is the most common species in domestic environments, occasionally forming colonies of more than 100 specimens $^{(5)}$ and having high levels of natural infection via Trypanosoma cruzi; thus, this species is one of the most efficient transmitters of CD to humans. Domestic infestation occurs more commonly during the dry season, and triatomines are usually attracted to light ${ }^{(6)}$.

In the wild, $T$. brasiliensis is associated with the Caatinga (a semi-arid scrub forest in northeastern Brazil) and is usually found in dens of various rodents ${ }^{(7)}$. Valença-Barbosa et al. ${ }^{(8)}$ recently examined the T. brasiliensis colonization of the Pilosocereus gounellei cactus, popularly known as xique-xique in the Valley of Jaguaribe, Northeastern Brazil. The proximity of wild and domestic environments enables the dispersion of insects to housing units ${ }^{(9)}$. In peridomiciles, T. brasiliensis shows a preference for animal shelters built with bricks and covered with tiles ${ }^{(5)}$. Rodrigues et al. ${ }^{(10)}$ have noted a strong tendency for T. brasiliensis to be located in poultry houses and near bird resting areas, especially in the lower, drier and warmer portions of walls. 
The proximity of wild and domestic environments in the northeastern semi-arid region enables an intense flow of T. brasiliensis between these environments. As such, reinfestation processes are frequently reported ${ }^{(11)(12)}$. In this sense, the use of residual insecticides is extremely relevant to prevent new specimens from invading housing units. However, despite systematic and continuous spraying activities in accordance with the recommendations of the Ministry of Health $^{(13)}$, controlling triatomines has been difficult in many areas. Diotaiuti et al. ${ }^{(12)}$ examined households in Independência four months after deltamethrin spraying and found triatomines of all development phases in $9.7 \%$ of the sampled units. This finding suggests that triatomine recolonization from neighboring locations occurs via specimens surviving the spraying process. This result might be related to operational failures in the spraying activity, $T$. brasiliensis resistance to the insecticides used for vector control, or both.

To better understand the factors that hinder the control of T. brasiliensis in the households of Ceará, Brazil, this study characterized the toxicological profile of deltamethrin pyrethroid in $T$. brasiliensis populatio across six municipalities using laboratory bioassays.

\section{METHODS}

The specimens for this study were manually collected without using a dislodging agent from peridomiciles in endemic areas of Ceará where the Chagas Disease Control Program had performed continuous and systematic applications of insecticides with residual action over the last 30 years: Jaguaruana (04 $\left.50^{\circ} 02^{\prime \prime} \mathrm{S} 37^{\circ} 46^{\prime} 51^{\prime \prime} \mathrm{W}\right)$, Quixeré $\left(05^{\circ} 04^{\prime}\right.$ $\left.26^{\prime \prime} \mathrm{S} 37^{\circ} 59^{\prime} 20^{\prime \prime} \mathrm{W}\right)$, Jaguaribe ( $\left.05^{\circ} 53^{\prime} 27^{\prime \prime} \mathrm{S} 38^{\circ} 37^{\prime} 19^{\prime \prime} \mathrm{W}\right)$, Independência $\left(05^{\circ} 23^{\prime} 45^{\prime \prime} \mathrm{S} 40^{\circ} 18^{\prime} 32^{\prime \prime} \mathrm{W}\right)$, Ipaporanga ( $04^{\circ}$ $\left.54^{\prime} 00^{\prime \prime} \mathrm{S} 40^{\circ} 45^{\prime} 32^{\prime \prime} \mathrm{W}\right)$, and Tauá $\left(06^{\circ} 00^{\prime} 10^{\prime \prime} \mathrm{S} 40^{\circ} 17^{\prime} 34^{\prime \prime}\right.$ W). Dr. Marcos Obara kindly provided a susceptibility reference lineage (SRL). This colony originated from the insectary of the Laboratory of Parasitology in the Department of Biological Sciences at Universidade Estadual Paulista Júlio de Mesquita Filho/UNESP. The insectary was started in 1984.

Bioassays were performed using the methods of Pessoa ${ }^{(14)}$ and the World Health Organization (WHO) $)^{(15)}$. Serial dilutions $(0.1-8.0 \mathrm{ng} / \mu \mathrm{L})$ of deltamethrin $(98.2 \%$ purity, Bayer: São Paulo, Brazil) were prepared and applied to the abdomen of the first instar nymphs from the $\mathrm{F} 1$ generation (five days old, fasting weight $1.2 \pm 0.2 \mathrm{mg})$ using a Hamilton micro-syringe $(0.5 \mu \mathrm{L}$ per insect). The insecticide was diluted in acetone. At least six doses surrounding the lethal dose of $50 \%\left(\mathrm{LD}_{50}\right)$ producing mortality rates between $10 \%$ and $90 \%$ were administered. Acetone alone was applied to the insects in the control group. Three replicates of ten nymphs were performed for each dose. Mortality was recorded at $72 \mathrm{~h}$. The mortality criterion was the inability of the nymphs to walk out of a filter paper disc $\left(7 \mathrm{~cm}\right.$ in diameter $\left.{ }^{(15)}\right)$.

The mortality data were analyzed using Basic Probit Analysis ${ }^{(16)}$ software to estimate slope and the $\mathrm{LD}_{50}$ in nanograms of active ingredient per treated nymph (ng a.i./nymph). Fifty percent resistance ratios $\left(\mathrm{RR}_{50}\right)$ were calculated by dividing the $\mathrm{LD}_{50}$ of each field population by its corresponding SRL. A susceptibility status classification was performed according to the Pan American Health Organization (PAHO) $)^{(17)}$.

After setting the base susceptibility line of the T. brasiliensis reference population, 30 nymphs from all of the field samples received a diagnostic dose of $1 \mathrm{xLD}_{99}(0.851 \mathrm{ng}$ a.i./nymph) based on the SRL. The survival of at least two insects in three replicates was interpreted as an indicator of resistance ${ }^{(15)}$.

\section{RESULTS}

The susceptibility reference lineage presented an $\mathrm{LD}_{50}$ of $0.293 \mathrm{ng}$ a.i./nymph treated. The susceptibility profile characterization of the T. brasiliensis samples revealed $\mathrm{RR}_{50}$ values ranging from 0.32 to 1.21 . The mortality percentage in response to the diagnostic dose for all samples was $100 \%$. Only six samples from Jaguaruana (Cipriano Lopes), Independência (Pajeú), Jaguaribe (Serrote), Quixeré (Boqueirão), Ipaporanga (Lagoa de Dentro, Casa 6) presented a slope less than the SRL, revealing higher frequencies of individuals with resistant alleles (Table 1).

\section{DISCUSSION}

The virtual control of T. infestans (a native species of Bolivia, introduced in the late $18^{\text {th }}$ century in Brazil) ${ }^{(18)}$, accompanied by the International Elimination of the Transmission of Chagas Disease Certificate in $2006^{(19)}$, strengthened the spurious idea that $\mathrm{CD}$ had been eliminated in Brazil and disregarded the epidemiological importance of native triatominic species in the Northeast region, such as T. brasiliensis. The significance of these triatomines with regard to maintaining the cycle of T. cruzi near human homes should not be neglected, hence the importance of control activities, epidemiological surveillance and health awareness. Despite systematic and continuous spraying activity, reinfestation has often been reported because of operational failures, resistance to the insecticides used in vector control strategies, or both.

Sonoda et al. ${ }^{(20)}$ found low levels of $T$. brasiliensis resistance to deltamethrin in populations in Tauá, Ceará. Intradomicile populations (Cachoeira dos Pedrosas $\mathrm{RR}_{50}=1.16$, Cachoeira do Júlio $\mathrm{RR}_{50}=1.74$, Dormideira $\mathrm{RR}_{50}=1.79$ and Mutuca $\mathrm{RR}_{50}=1.58$ ), peridomicile populations (Cachoeira dos Pedrosas $\mathrm{RR}_{50}=1.26$, Morada Nova do Thomas $\mathrm{RR}_{50}=1.74$ and Mutuca $\mathrm{RR}_{50}=1.58$ ) and wild populations (Cachoeira dos Pedrosas $\mathrm{RR}_{50}=1.0$ ) were assessed, and all were categorized as highly susceptible to the tested insecticide.

Obara $^{(21)}$ characterized the toxicological profile of 16 populations of $T$. brasiliensis with regard to deltamethrin in the States of Paraíba, Pernambuco, Piauí and Rio Grande do Norte. All of these populations presented low $\mathrm{RR}_{50}$ values ranging from 1.0 to 2.17. Field trials to assess the effect of WG250 deltamethrin at $25 \mathrm{ng}$ a.i./nymph on different substrates (as recommended by the Ministry of Health) have confirmed the susceptibility of all populations, with $100 \%$ mortality rates for all trials. 
TABLE 1 - Toxicity of topically applied deltamethrin to Triatoma brasiliensis first instars of an SRL and peridomestic samples collected from State of Ceará, Brazil.

\begin{tabular}{|c|c|c|c|c|c|}
\hline Population: Municipality; Location & Number* & $\mathrm{LD}_{50}(95 \% \mathrm{CIs})$ & $\mathrm{RR}_{50}$ & Slope (SD) & $\begin{array}{c}\text { Diagnostic } \\
\text { dose } \\
\text { (\% mortality) }\end{array}$ \\
\hline Jaguaruana; Cipriano Lopes & 330 & $0.093(0.075-0.114)$ & 0.32 & $2.358 \pm 0.376$ & 100.0 \\
\hline Quixeré; Boqueirão do Adauto & 330 & $0.112(0.09-0.126)$ & 0.38 & $5.096 \pm 0.855$ & 100.0 \\
\hline Jaguaribe; Alto Grande & 330 & $0.176(0.154-0.207)$ & 0.60 & $3.871 \pm 0.656$ & 100.0 \\
\hline Independência; Cachoeira do Lopes & 300 & $0.188(0.148-0.231)$ & 0.64 & $3.527 \pm 0.610$ & 100.0 \\
\hline Ipaporanga; Serrinha & 270 & $0.221(0.118-0.255)$ & 0.75 & $4.427 \pm 1.896$ & 100.0 \\
\hline Independência; Pajeú & 240 & $0.220(0.119-0.290)$ & 0.75 & $2.421 \pm 0.567$ & 100.0 \\
\hline Quixeré; Boqueirão & 300 & $0.274(0.226-0.350)$ & 0.93 & $2.512 \pm 0.410$ & 100.0 \\
\hline Ipaporanga; Alegre - Casa 6 & 240 & $0.275(0.141-0.412)$ & 0.94 & $1.422 \pm 0.480$ & 100.0 \\
\hline Ipaporanga: Lagoa de Dentro & 270 & $0.299(0.257-0.356)$ & 1.02 & $2.884 \pm 0.432$ & 100.0 \\
\hline Tauá; Viração & 270 & $0.348(0.318-0.381)$ & 1.19 & $5.043 \pm 0.673$ & 100.0 \\
\hline Ipaporanga; Alegre - Casa 5 & 270 & $0.355(0.310-0.410)$ & 1.21 & $4.053 \pm 0.578$ & 100.0 \\
\hline Jaguaruana; Currais do Felipe & 240 & $0.354(0.303-0.561)$ & 1.21 & $3.063 \pm 0.529$ & 100.0 \\
\hline
\end{tabular}

SRL: susceptibility reference lineage; $\mathbf{L D}_{\mathbf{5 0}}: 50 \%$ lethal dose; $95 \%$ CIs: $95 \%$ confidence intervals; $\mathbf{R R}_{\mathbf{5 0}}: 50 \%$ resistance ratio; $\mathbf{S D}$ : standard deviation. * number of triatomines used.

This work assessed 15 populations of T. brasiliensis from Ceará and identified low $\mathrm{RR}_{50}$ values (0.32-1.21). According to the WHO (1994), all populations are susceptible to deltamethrin. In the present study, the qualitative assays confirmed this susceptibility and showed $100 \%$ mortality rates for all of the samples in response to diagnostic dose. Importantly, populations from different locations within the same municipality presented different toxicological profiles. This finding suggests that the selection process for pesticides can occur independently, even in neighboring houses ${ }^{(22)(23)}$.

The existence of populations with $\mathrm{RR}_{50}<1.0$ (i.e., those more susceptible than the susceptibility reference strain used) suggests that the SRL already had resistant alleles when it was collected in the field in 1984 and that they remain to the present day. A similar finding was reported for Triatoma sordida ${ }^{(23)(24)}$, which led us to reflect on the weak criteria recommended by the $\mathrm{PAHO}^{17}$ for the choice of SRLs: over five generations in the laboratory without insecticide contact, external material contribution, or originating from places that have never been treated with insecticide.

Of the 15 populations studied, 9 presented slopes equal to or greater than the SRL, suggesting little intrapopulational heterogeneity. This finding corroborates molecular studies showing that genetic diversity is lower in areas with chemical treatment than untreated areas ${ }^{(25)(26)(27)}$. However, the other 6 populations showed lower slopes than the SRL, indicating greater heterogeneity most likely because of the high dispersal rates of the T. brasiliensis specimens in Ceará that invade houses by flying $^{(12)}$. This fact shows the significant recolonization potential of artificial environments from wild and peridomicile sources. Importantly, one cannot exclude the possible development of resistance among populations with lower slopes than that of the SRL when pressured by insecticides. This possibility justifies the need to monitor timeline susceptibility changes.

The results obtained from qualitative and quantitative bioassays did not prove that $T$. brasiliensis is resistant to deltamethrin. Despite successive insecticide spraying, the persistence of triatomines might be associated with their behavior. Peridomicile (and even intradomicile) infestations present a wide range of environments, corresponding to an infinite number of hiding spots. Spraying these environments requires extensive work; unstacking all of the material accumulated inside is often impossible for field agents. Consequently, triatomines (eggs, nymphs and adults) might remain in the area after insecticide application, having no or limited contact with the chemical, thereby encouraging the selection of those that are least susceptible and enabling their survival ${ }^{(28)(29)}$. Moreover, the high temperatures and ultraviolet (UV) radiation of northeastern Brazil can degrade pyrethroids faster, thereby reducing their duration, availability on treated surfaces, and their consequent triatomicide action. 
Importantly, the small changes in susceptibility found in this study are unlikely to have contributed to the emergence of CD cases in the study area; however, they serve as a warning to improve the quality and methodological rigor of the chemical control activities associated with the spatial reordering of households to avoid refractory $T$. brasiliensis.

\section{ACKNOWLEDGMENTS}

We are grateful to Dr. Marcos Obara for providing the SRL and Bayer S.A. for providing the insecticide.

\section{CONFLICT OF INTEREST}

The authors declare that there is no conflict of interest.

\section{FINANCIAL SUPPORT}

The Conselho Nacional de Desenvolvimento Cientifico e Tecnológico (CNPq), Centro de Pesquisas René Rachou (CPqRR), Fundação Oswaldo Cruz (FIOCRUZ), Secretaria de Vigilância em Saúde (SVS), Ministério da Saúde (MS) - Brazil and the World Health Organization (WHO) provided financial support.

\section{REFERENCES}

1. Schofield CJ, Jannin J, Salvatella R. The future of Chagas disease control. Trends Parasitol 2006; 22: 583-588.

2. Walter A, Rego IP, Ferreira AJ, Rogier C. Risk factors for reinvasion of human dwellings by sylvatic triatomines in northern Bahia State, Brazil. Cad Saude Publ 2005; 21:974-978.

3. Soares RPP, Evangelista LG, Laranja LS, Diotaiuti L. Population dynamics and feeding behaving behavior Triatoma brasiliensis and Triatoma pseudomaculata, main vectors of Chagas disease in northeastern Brazil. Mem Inst Oswaldo Cruz 2000; 95: 151-155.

4. Sarquis O, Borges-Pereira J, Mac Cord JR, Gomes TF, Cabello PH, Lima MM. Epidemiology of Chagas disease in Jaguaruana, Ceará, Brazil. I. Presence of triatomines and index of Trypanosoma cruzi infection in four localities of rural area. Mem Inst Oswaldo Cruz 2004; 99:263-270.

5. Sarquis O, Sposina R, Oliveira TG, Mac Coard JR, Capello PH, Borges-Pereira J, et al. Aspects of peridomiciliary ecotopes in rural areas of northeastern Brazil associated to triatomine (Hemiptera, Reduviidae) infestation, vectors of Chagas disease. Mem Inst Oswaldo Cruz 2006; 101:143-147.

6. Carvajal de La Fuente AL, Minoli AS, Lopes CM, Noireau F, Lazzari CR, Lorenzo MG. Flight dispersal of the Chagas disease vectors Triatoma brasiliensis and Triatoma pseudomaculata in northeastern Brazil. Acta Trop 2007; 101:115-119.

7. Lent H, Oliveira SJ. Nota preliminar sobre a ação do DDT (diclorodifenil-tricloetano) em insetos transmissores da doença de Chagas. Rev Bras Biol 1944; 4:329-331.

8. Valença-Barbosa C, Lima MM, Sarquis O, Bezerra CM, AbadFranch F. A common Caatinga cactus, Pilosocereus gounellei, is an important ecotope of wild Triatoma brasiliensis populations in the Jaguaribe valley of northeastern Brazil. Am J Trop Med Hyg 2014; 90:1059-1062.

9. Borges EC, Dujardin JP, Schofield CJ, Romanha AJ, Diotaiuti L. Dynamics between sylvatic, peridomestic and domestic populations of Triatoma brasiliensis (Hemiptera: Reduviidae) in Ceará State, northeastern Brazil. Acta Trop 2005; 93:119-126.

10. Rodrigues VLCC, Ferraz-Filho AN, Ishihata GK, Silva EOR. Triatoma brasiliensis Neiva, 1911 (Hemiptera, Reviidae): observações sobre seu comportamento em relação à fonte alimentar em galinheiro experimental. Cad Saude Publ 1995; 11:226-270.

11. Dias JCP. Epidemiologia. In: Brener Z, Andrade ZA, Barral-Netto M. Trypanosoma cruzi e Doença de Chagas. $2^{\mathrm{a}}$ edition, Editora Guanabara Koogan, Rio de Janeiro: 2000; p.48-74.

12. Diotaiuti L, Faria Filho OF, Carneiro FCF, Dias JCP, Pires HHR, Schofield CJ. Aspectos operacionais do controle do T. brasiliensis. Cad Saude Publ 2000; 16:61-67.

13. Ministério da Saúde. Portaria $n^{0} 1.172$, de 15 de junho de 2004. Regulamenta a NOB SUS 01/96 no que se refere às competências da União, Estados, Municípios e Distrito Federal, na área de Vigilância em Saúde, define a sistemática de financiamento e dá outras providências. Diário Oficial da União. 15 jun. 2004.

14. Pessoa GCD: Monitoramento da suscetibilidade ao piretróide deltametrina em populações de Triatoma sordida Stal, 1859 (Hemiptera: Reduviidae). Dissertação de Mestrado, Centro de Pesquisas René Rachou, Fundação Oswaldo Cruz; Belo Horizonte: 2008; 95p.

15. World Health Organization (WHO). Taller sobre la evaluación de efecto insecticida sobre triatominos. Workshop on the insecticide effect evaluation in triatominos. Acta Toxicol Argentina 1994; 2:29-33.

16. Finney DJ. Probit analysis. Ann Appl Biol 1971; 36:187-195.

17. Organización Panamericana de la Salud (PAHO). II Reunion técnica latinoamericana de monitoreo de resistência a insecticidas em triatominos vectores de Chagas, OPS. Panamá: PAHO; 2005.

18. Dias JCP. Control of Chagas Disease in Brazil. Parasitol Today 1987; 3:336-341.

19. Dias JCP. Doença de Chagas: sucessos e desafios. Cad Saude Publica 2006; 22:2020-2021.

20. Sonoda IV. Triatoma infestans e Triatoma brasiliensis: avaliação da resistência ao piretróide deltametrina e análise intraespecífica da variabilidade genética. Tese de doutorado. Centro de Pesquisas René Rachou da Fundação Oswaldo Cruz; Belo Horizonte: 2009; 96p.

21. Obara TM. Caracterização de resistência a inseticidas em populações da subfamília Triatominae (Hemiptera: Reduviidae), vetores de Trypanosoma cruzi Chagas, 1909. Tese de doutorado, Universidade de São Paulo, São Paulo: 2010; 246p.

22. Germano MD, Picollo MI, Mouganbure-Cueto GS. Microgeographical study of insecticide resistance in Triatoma infestans from Argentina. Acta Tropica 2013; 128:561-565.

23. Pessoa GCD, Dias LS, Diotaiuti L. Deltamethrin pyrethroid susceptibility characterization of Triatoma sordida Stal, 1859 (Hemiptera: Reduviidae) populations in the Northern Region of Minas Gerais, Brazil. Soc Bras Med Trop 2014; 47:426-429.

24. Pessoa GCD. Perfil da suscetibilidade a deltametrina em populações de Triatoma sordida (Hemiptera: Reduviidae) do Estado de Minas Gerais procedentes de áreas com infestação persistente. Tese de Doutorado, Universidade Federal de Minas Gerais, Belo Horizonte: 2012; 179p.

25. Rojas de Arias A, Lehane MJ, Schofield CJ, Fournet A. Comparative evaluation of pyrethroid insecticide formulations against 
Triatoma infestans (Klug): residual efficacy on four substrates. Mem Inst Oswaldo Cruz 2003; 98:975-980.

26. Perez de Rosas AR, Segura EL, García BA. Microssatellites analysis of genetic structure in natural Triatoma infestans (Hemiptera: Reduviidae) populations from Argentina: its implication in assessing the effectiveness of Chagas disease vector control program. Mol Ecol 2007; 16:1401-1412.

27. Perez AR, Segura EL, Fichera L, Garcia BA. Macrogeographic and microgeographic genetic structure of the Chagas disease vector
Triatoma infestans (Hemiptera: Reduviidade) from Catamarca, Argentina. Genetica 2008; 133:247-260.

28. Diotaiuti L, Pinto CT. Suscetibilidade biológica do Triatoma sordida e Triatoma infestans a deltametrina e lambdacyalotrina em condições de campo. Rev Soc Bras Med Trop 1991; 24:151-155.

29. Diotaiuti L, Azeredo BVM, Busek SCU, Fernandes AJ. Controle do Triatoma sordida no Peridomicílio Rural do Município de Porteirinha, Minas Gerais, Brasil. Rev Pan Salud Pub 1998; 3:21-25. 